\title{
ANALISIS FAKTOR-FAKTOR DALAM MENINGKATKAN KESUKSESAN PRODUK BARU PADA KINERJA PEMASARAN \\ (Studi Kasus pada Produk Telepon Seluler Polytron atau

\author{
PT. Hartono Istana Teknologi)
}

\author{
Bun Norikun \\ DC. Kuswardani \\ Fakultas Ekonomi Universitas Semarang
}

\begin{abstract}
This research aims to examine the effect of Usabilitythe productand New product advantages in improving the success of new products that can affect the marketing performance. The objectof this researchisPT. HartonoIstana TeknologiKudus.The sample wasconsumers whoeverbuyandusedmobile phonesPolytron. Atthis experimentusing97respondents.

The techniques analysis usedis thetwo-stage regressionwithclassical assumptions. The result of regression is: $Y_{1}=0.100 X_{1}+0.624 X_{2}$ and $Y_{2}=0.569$ $Y_{1}$.Based on the hypothesis that analysis is showednosignificanteffecton the level ofproductusabilitysuccessof new products, There is asignificant influencebetween thenewproduct advantageto the levelof successof new products, There is a significant influence between the level of success of new products to marketing performance. Sobel test results that influence the usefulness of the product for marketing performance with mediation success rate of new products is to strengthen, whereas the effect new product advantages on the marketing performance to mediation success rate of new products is to strengthen.
\end{abstract}

Keywords: Usability the product, Newproduct advantages, The level of success of new products, Marketingperformance.

Abstract: Penelitian ini bertujuan untuk menguji pengaruh Kegunaan produk dan Keunggulan produk baru dalam meningkatkan kesuksesan produk baru yang mampu mempengaruhi kinerja pemasaran. Objek penelitian ini adalah PT. Hartono Istana Teknologi Kudus.Sampel penelitian ini adalah konsumen yang pernahmembeli dan menggunakan telepon seluler Polytron.Pada penelitn ini menggunakan 97 responden.

Teknik analisis yang digunaan adalah regresi dua tahap dengan asumsi klasik. Hasil persamaan regresinya adalah $Y_{1}=0.100 X_{1}+0.624 X_{2}$ dan $Y_{2}=0.569 Y_{1}$. Berdasarkan pada analisis hipotesis yaitu menunjukkan tidak ada pengaruh signifikan antara kegunaan produk terhadap tingkat kesuksesan produk baru, ada pengaruh signifikan antara keunggulan produk baru terhadap tingkat kesuksesan produk baru, ada pengaruh signifikan antara tingkat kesuksesan produk baru terhadap kinerja pemasaran.Hasil uji sobel mengatakan pengaruh kegunaan produk terhadap kinerja pemasaran dengan mediasi tingkat kesuksesan produk baru adalah menguatkan, sedangkan pengaruh keunggulan produk baru terhadap kinerja pemasaran dengan mediasi tingkat kesuksesan produk baru adalah menguatkan.

Kata kunci : Kegunaan produk, Keunggulan produk baru, Tingkat kesuksesan produk baru, Kinerja pemasaran. 


\section{PENDAHULUAN}

Perkembangan dan kemajuan teknologi pada era milenium yang pesat seperti sekarang ini munculnya suatu peluang dan tantangan pada perusahaan elektronik khususnya di Indonesia. Permintaan yang tinggi dari pasar, menginginkan suatu produk elektronik yang canggih dan kebutuhan masyarakat akan sarana-sarana komunikasi yang mendukung saat ini sangat penting dan menyebabkan persaingan dalam dunia bisnis antara perusahaan pengembang elektonik di Indonesia menjadi semakin kompetitif.

Pemerintah Indonesia sangat mendukung perkembangan dan kemajuan teknologi, banyaknya investor-investor dari luar yang masuk ke Indonesia untuk berbinis dibidang teknologi. Hal ini membuat perusahaan local menjadi tertantang akan pengembangan teknologi di Indonesia. Menteri Komunikasi dan Informatika (Menkominfo) Rudiantara pada Senin, 23 Februari 2015 di PT. Hartono Istana Teknologi kudus menegaskan untuk produk eletronika mengharuskan Ponsel (Telepon Seluler) yang di pasarkan di Indonesia harus menggunakan TKDN (Tingkat Kandungan Dalam Negeri) telepon seluler harus sebesar 20\% pada tahun 2015 dan naik 40\% per 1 januari 2017. Hal ini berarti investor harus mempunyai pabrik dan produksi di Indonesia. Berdasarkan Regulasi TKDN saat ini : a). Kemendag: Permendag No. 82/2012 tentang ketentuan impor telepon seluler, b). Kemenperin: Permenperin No. 69/2004 tentang ketentuan dan tata cara penghitungan nilai TKDN industry elektronika dan telematika, c). Kemkominfo: Segera menerbitkan peren tentang persyaratan teknis alat dan perangkat telekomunikasi berbasis standar teknologi Long Term Evolution.

Kesempatan ini tentunya tidak begitu saja dilewatkan oleh perusahaan elektronik dalam membangun dan meningkatkan kinerja pemasaran yang dapat mengukur prestasi dalam perusahaan untuk bersaing dengan perusahaanperusahaan lainnya.Diantara banyaknya perusahaan yang bergerak di bidang elektronik dan informasi di Indonesia, salah satunya adalah PT. Hartono Istana Teknologi ( HIT ) yang bergerak pada bidang manufaktur elektronik dengan merk dagang polytron. Pada tahun 2014 penjualan telepon seluler Polytron lebih tidak sering mencapai target penjualan yang telah ditetapkan oleh perusahaan, kondisi 
ini menandakan bahwa masih adanya permasalahan pada kinerja pemasaran yang kurang baik.Potensi kinerja pemasaran pada PT. HIT sangat penting yang dapat mengukur prestasi pemasaran dengan volume penjualan, pertumbuhan penjualan, dan pertumbuhan pelanggan, dalam Ferdinand (2000) dan Samtim (2003).Sedangkan dilihat dari pertumbuhan penjualan untuk mengukur kinerja pemasaran dalam penjualan telepon seluler mengalami fluktuatif.Pertumbuhan penjualan merupakan indikator dari penerimaan pasar atas produk atau jasa yang dihasilkan, dan pendapatan yang dihasilkan dari penjualan tersebut dapat digunakan untuk mengukur tingkat pertumbuhan penjualan (Rian Muharsyah).

Menurut Song dan Parry, 1997,p.67 (Okki). Salah satu hal penting dalam tujuan pemasaran yang perlu diperhatikan oleh perusahaan adalah membuat suatu ukuran atau standard untuk meningkatkan kinerja perusahaan seperti kinerja pemasaran yang meningkat. Menurut Ferdinand, 2000, p.9 (Okki) mengatakan kinerja pemasaran merupakan konsep untuk mengukur prestasi pemasaran suatu produk.Kinerja pemasaran merupakan faktor yang umum digunakan untuk mengukur hasil dari sebuah strategi perusahaan.Ferdinand (Ferdinand,2013:104)mengungkapkan kinerja pemasaran dapatdiukur dengan adanya peningkatan volumepenjualan, pertumbuhan pelanggan, dan pertumbuhan penjualan. Samtim (2003, p.94) juga mengatakan dalam penelitiannya kinerja pemasaran menggunakan indikator-indikator yang berupa volume penjualan, pertumbuhan pelanggan, dan pertumbuhan penjualan sebagai instrument yang digunakan untuk mengukur dampak dari strategi yang diterapkan perusahaan.

Penelitiannya Okki Navarone (2003), mendukung bahwa meningkatkan kinerja pemasaran terdapat variable yang mempengaruhi yaitu promosi, pengelolaan pengetahuan konsumen, keunggulan produk baru, dan tingkat kesuksean produk baru yang mempengaruhi kinerja pemasaran.

Li dan Calantone (1998, p.13) mengatakan bahwa kesuksesan produk baru antara lain terkait dengan keunikan dan kekinian produk merupakan suatu keunggulan dari produk. Hal ini bila dibandingkan dengan produk lainnya menjadi salah satu faktor yang menentukan sukses tidaknya produk tersebut. 
Berdasarkan refrensi dan penelitian terdahulu, maka perlu dilakukan penelitian yang berkaitan dengan kinerja pemasaran PT. HIT. Menurut beberapa peneliti terdahulu atau beberapa ahli untuk mengukur kinerja pemasaran yaitu dengan volume penjualan,pertumbuhan pelanggan, dan pertumbuhan penjualan. Meningkatkan kinerja pemasaran dalam penelitian ini menggunkan kegunaan produk, keunggulan produk baru, tingkat kesuksesan produk yang akan mempengaruhi kinerja pemasaran (Okki dan Fitri).

Berdasarkan uraian diatas, maka judul penelitian ini adalah "ANALISIS

\section{FAKTOR-FAKTOR DALAM MENINGKATKAN KESUKSESAN PRODUK BARU PADA KINERJA PEMASARAN (Studi Kasus pada Produk Telepon Seluler Polytron atau PT. Hartono Istana Teknologi)"}

\section{TINJAUN PUSTAKA}

\section{Kegunaan Produk}

Suatu kepercayaan konsumen dalam menggunakan produk sehari-hari yang dapat memenuhi kebutuhannya.Kegunaan produk dapat diukur melalui kegunaan produk untuk berkomunikasi, mendapat informasi, transaksi keuangan, pentingnya produk pada pekerjaan.Jadi kegunaan produk/mengacu pada kemampuan produk untuk memenuhi kebutuhan konsumen.

\section{Keunggulan Produk Baru}

Song dan Parry (1997) dalam penelitian Okki (2003) menyatakan bahwa keunggulan suatu produk baru/merupakan salah satu factor penentu dari kesuksesan produk baru, pernyataan ini didukung oleh Reinerstein dan Smith (Zahra, 1993) dalam penelitian Okki menyatakan bahwa keunggulan produk baru merupakan hal yang vital bagi kesuksesan produk baru yang di hasilkan oleh perusahaan.

Li dan Calanton (1998,p.17) menunjukkan bahwa keunggulan dari produk baru adalah berkaitan dengan atribut produk (seperti kualitas, teknologi, dapat dipercayanya suatu produk baru, hal-hal baru dan keunikannya) yang dapat memberikan gambaran lebih konkret dari kemampuan perusahaan untuk memahami, memenuhi kebutuhan pelanggannya dan alternatif serta bukti 
langsung dari keunggulannya. Jadi keunggulan produk baru adalah suatu produk yang terlihat menarik dari produk lain, lebih tinggi spesifikasi, serta dapat memuaskan konsumen. keunggulan produk baru dapat diukur melalui desain unik, kualitas produk, trend/kekinian, teknologi atau kehandalan, produk benar-benar baru dan inovatif.

\section{Tingkat Kesuksesan Produk Baru}

Menurut Sridhar Samu (Okki, 2003) indikator bahwa suatu produk perusahaan sukses atau tidak di pasar antara lain adalah seberapa jauh tumbuhnya minat beli, prioritas produk yang dibeli dan, keputusan konsumen untuk membeli kembali varian produk tersebut di waktu yang lain.

Menurut Mittal (Okki), dapat dikatakan minat seseorang akan melahirkan frekuensi pembelian atau pembelian ulang oleh karena itu dimensi minat pembelian adalah besarnya minat atau seberapa besar kemungkinan terjadinya suatu pembelian oleh konsumen.

Mengacu pernyataan Sridhar Samu dan di dukung oleh penelitian okki dan fitri menyatakan bahwa tingkat kesuksesan produk baru adalah suatu poduk yang membuat tertarik konsumen dan keputusan konsumen untuk membeli kembali varian produk. Tingkat kesuksesan produk baru dapat diukur dengan seberapa jauh tumbuhnya minat pembeli, prioritas produk yang dibeli, keputusan konsumen untuk membeli kembali varian produk pada waktu lain.

\section{Kinerja Pemasaran}

Ferdinand (2000, p.23) menyatakan bahwa kinerja pemasaran merupakan konsep untuk mengukur prestasi pemasaran suatu produk.Kinerja pemasaran merupakan faktor yang umum digunakan untuk mengukur hasil dari sebuah strategi perusahaan.

Kinerja pemasaran dapat diukur dengan adanya peningkatan : volume penjualan, Pertumbuhan pelanggan, pertumbuhan penjualan (Ferdinand, 2013:104). Penelitian Samtim Eko Putranto (2003) juga mendukung pernyataan diatas yaitu pertumbuhan penjualan, pertumbuhan pelanggan, dan volume penjualan sebagai alat pengukuran kinerja pemasaran perusahaan. 
Mengacu pada pernyataan Ferdinand dan di dukung oleh penelitian Samtim Eko Putranto (2003) mengungkapkan bahwa indicator kinerja pemasaran adalah volume penjualan, pertumbuhan pelanggan, dan pertumbuhan nilai penjualan. Pada study ini mengembangkan kinerja pemasaran dapat diukur dengan keunggulan harga, purna jual, saluran produk / distribusi.

\section{Penelitian Terdahulu}

Penelitian terdahulu yang dilakukan Okky (2003) menyatakan bahwa terdapat pengaruh positif dan signifikan antara variabel keunggulan produk baru yang mempengaruhi tingkat kesuksesan produk baru dalam meningkatkan kinerja pemasaran.

Nurul \& Fitri (2006) mengungkapkan bahwa ada pengaruh positif dan signifikan antara variable kegunaan produk, keunggulan produk baru terhadap tingkat kesuksesan produk baru.Artinya semakin tinggi kegunaan produk dan keunggulan roduk baru menurut konsumen maka akan semakin tinggi juga tingkat kesuksesan produk baru.

\section{Kerangka Pemikiran}

Penelitian ini dapat dibuat suatu kerangka pemikiran yang dapat menjadi landasan dalam penulisan ini yang pada akhirnya dapat diketahui variabel mana yang paling dominan dalam mempengaruhi Tingkat Kesuksesan Produk Baru (sebagai variable intervening) dan terhadap Kinerja Pemasaran (sebagai variable terikat). Kerangka pikiran ini dapat digambarkan sebagai berikut :

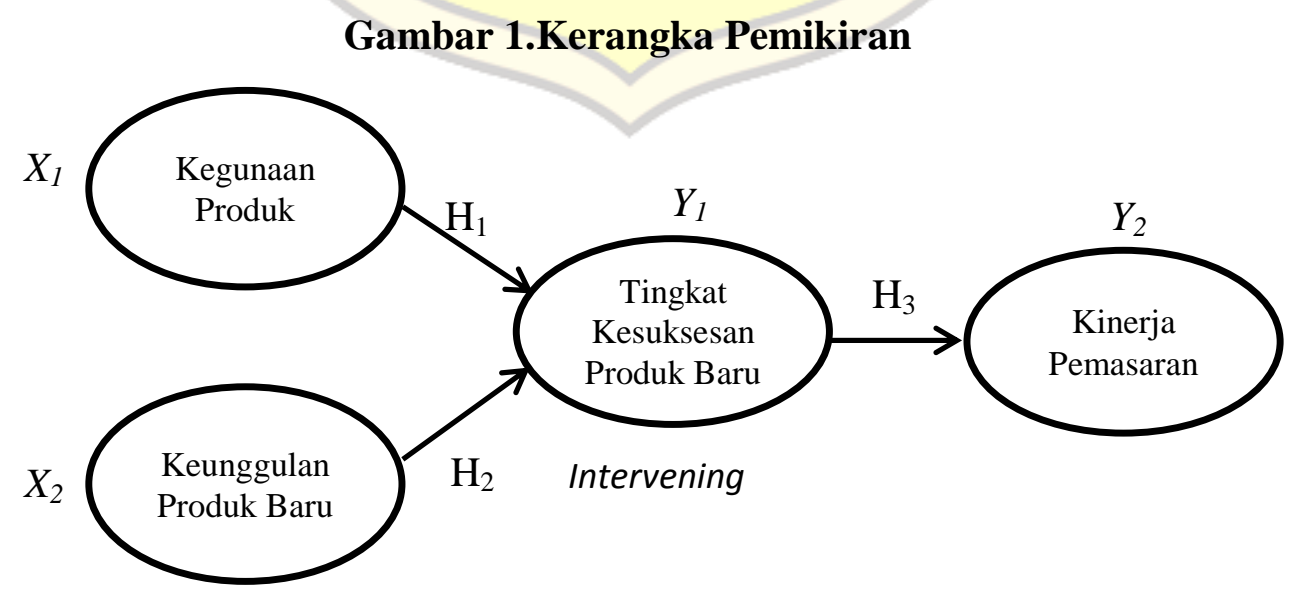




\section{HIPOTESIS}

$\mathrm{H}_{1}$ :Semakin tinggi kegunaan produk menurut konsumen, maka semakin tinggi tingkat kesuksesan produk.

$\mathrm{H}_{2}$ :Semakin tinggi keunggulan produk baru menurut persepsi konsumen, maka semakin tinggi pula tingkat kesuksesan produk.

$\mathrm{H}_{3}$ :Semakin tinggi kesuksesan produk baru, maka semakin meningkat pula kinerja pemasaran.

\section{METODELOGI PENELITIAN}

\section{Populasi dan Penentuan Sampel}

Populasi adalah wilayah generalisasi yang terdiri atas : obyek/subyek yang mempunyai kualitas dan karakteristik tertentu yang ditetapkan oleh peneliti untuk dipelajari dan kemudian ditarik kesimpulannya (Sugiyono, 2014:80).Populasi dalam penelitain ini yaitupara konsumen yang pernah membeli dan menggunakan produk Telepon Seluler merek Polytron dengan jumlah terlalu besar dan belum diketahui secara pasti.

Metode yang digunakan dalam pengambilan sampel ini adalahpurposive sampling yaitu teknik pengambilan sampel berdasarkan pertimbangan tertentu (Sugiyono,2014:84-85). Berdasarkan populasi yang belum diketahui secara pasti dan penentuan sampel, jika populasinya besar dan jumlahnya tidak diketahui maka menurut Rao (Fitri, 2006), digunakan rumus:

$$
\begin{aligned}
& n=\frac{2}{4(m o e)^{2}}=\frac{1,96^{2}}{4(0,1)^{2}} \\
& n=96,04
\end{aligned}
$$

Hasil perhitungan rumus di atas, jumlah sampel yang akan diteliti sebanyak 96,04 dan menjadi 97 responden.Adapun kriteria yang digunakan untuk mendapatkan 97 responden antara lain sebagai berikut :

1. Konsumen yang pernah membeli produk telepon seluler merek Polytron. 
2. Responden yang minimal berusia 20 tahun, karena di usia tersebut pengalaman responden dianggap cukup, sehingga mampu memberikan penilaian objektif.

\section{Jenis dan Sumber Data}

Jenis data yang digunakan dalam penelitian ini adalah data primer dan sekunder.Data Primer merupakan data yang didapat dari sumber pertama, misalnya dari individu atau perseseorangan, seperti hasil wawancara, pengisian kuesioner (Husain Umar, 2003;60). Data Sekunder merupakan data primer yang telah diolah lebih lanjut(table, grafik, diagram) sehingga lebih informatif jika digunakan oleh pihak lain (Husain Umar, 2003;60).Data primer dalam penelitian ini meliputi data yang diperoleh dari hasil penyebaran kuesioner dan tanggapan.Data Sekunder dalam penelitian ini meliputi data mengenai gambaran umum dan perkembangan PT. HIT, Data penjualan telepon seluler polytron PT. HIT.

\section{Metode Pengumpulan Data}

Metode pengumpulan data yang digunakan dalam penelitian ini adalah menggunakan kuesioner secara tertutup. Kuesioner tersebut menggunakan skala likert dimana skala dengan rentang skor satu sampai lima. Penskoran dilakukan dengan kriteria sebagai berikut :

$>\mathrm{SS}$

$>\mathrm{S}$

$>\mathrm{CS}$

$>\mathrm{TS}$

$>$ STS
: Sangat setujumendapat skor 5

: Setuju mendapat skor 4

: Cukup setuju mendapat skor 3

: Tidak setuju mendapat skor 2

: Sangat tidak setuju mendapat skor 1

\section{Metode Analisis}

\section{Analisis Regresi Linier}

Metode analisis yang digunakan adalah regresi linier dua tahap.Ferdinand (2013) mengatakan regresi linier dua tahap yaitu model regresi menunjukan 
bahwa variable dependen $\mathrm{Y}_{1}$ (variable intervening yaitu tingkat kesuksesan produk baru) dipengaruhi oleh beberapa variable independen (kegunaan produk, keunggulan produk baru).Sementara itu variable dependen yang kedua yaitu $\mathrm{Y}_{2}$ (kinerja pemasaran). Berikut model persamaan regresi linier dua tahap:

$$
\begin{aligned}
& Y_{1}=\alpha+\beta_{1} X_{1}+\beta_{2} X_{2}+\mu_{0} \\
& Y_{2}=\alpha+\beta_{3} Y_{1}+\mu_{1}
\end{aligned}
$$

Dimana:

$$
\begin{array}{ll}
\alpha & =\text { Konstanta } \\
\beta_{1}, \beta_{2}, \beta_{3} & =\text { Koefisien garis regresi } \\
\mu_{0,} \mu_{1} & =\text { Error / variabel pengganggu } \\
\mathrm{X}_{1}, \mathrm{X}_{2} & =\text { Variabel independen (kegunaan produk, Keunggulanproduk } \\
& \text { baru) } \\
\mathrm{Y}_{1} & =\text { Variabel dependen satu (intervening : tingkat kesuksesan produk } \\
& \text { produk baru) } \\
\mathrm{Y}_{2} & =\text { Variabel dependen dua(kinerja pemasaran) }
\end{array}
$$

\section{Koefisien Determinasi atau Uji Adjusted $\mathbf{R}^{2}$}

Menurut Ghozali (2012:97), Koefisien determinasi atau uji adjusted R $^{2}$ digunakan untuk mengukur seberapa jauh kemampuan model dalam menerangkan variasi variabel dependen (terikat). Besarnya nilai $\boldsymbol{R}^{2}$ adalah $0 \leq \boldsymbol{R}^{2} \leq 1$, dimana semakin mendekati 1 berarti model tersebut dapat dikatakan baik atau variabelvariabel independen memberikan hampir semua informasi yang dibutuhkan untuk memprediksi variabel dependen.

\section{Uji Hipotesis (Uji t)}

Menurut Priyatno (2010:86), menyatakan uji t digunakan ntuk menguji pengaruh variable independen secara persial terhadap variable dependen.Penerimaan hipotesis alternatif, yang menyatakan bahwa semua variabel independen secara individual mempengaruhi variabel dependen :

1. Apabila nilai probabilitas $\leq 5 \%$, maka $\mathrm{H} 0$ ditolak.

2. Apabila nilai probabilitas $\geq 5 \%$ maka $\mathrm{H} 0$ diterima. 
3. Membandingkan nilai statistik $\mathrm{t}$ dengan titik kritis menurut table. Bila nilai $\mathrm{t}$ hitung $\geq$ nilai t table, maka $\mathrm{HO}$ ditolak dan menerima HA, yang menyatakan bahwa suatu variable independen secara individual mempengaruhi variable dependen.

\section{Sobel Test}

Sobel Test digunakan untuk menguji pengaruh tidak langsung dari keunggulan produk baru terhadap kinerja pemasaran melalui tingkat kesuksesan produk baru sebagai variabel mediator atau intervening.

\section{HASIL DAN PEMBAHASAN}

Penelitian ini dilakukan pengujian hipotesis dengan menggunakan analisis regresi dua tahap dengan menggunakan bantuan program SPSS versi 22. Berikut ini hasilnya:

Tabel 1. Analisis Regresi (uji t)

Koefisien regresi untuk $\mathrm{Y}_{1}$ (Tingkat kesuksesan produk baru)

\section{Coefficients $^{\mathrm{a}}$}

\begin{tabular}{|c|c|c|c|c|c|c|}
\hline \multirow{2}{*}{\multicolumn{2}{|c|}{ Model }} & \multicolumn{2}{|c|}{$\begin{array}{l}\text { Unstandardized } \\
\text { Coefficients }\end{array}$} & \multirow{2}{*}{$\begin{array}{c}\begin{array}{c}\text { Standardized } \\
\text { Coefficients }\end{array} \\
\text { Beta }\end{array}$} & \multirow[b]{2}{*}{$t$} & \multirow[b]{2}{*}{ Sig. } \\
\hline & & $\mathrm{B}$ & Std. Error & & & \\
\hline & (Constant) & 2.409 & 1.153 & & 2.091 & .039 \\
\hline & kegunaan produk & .091 & .080 & .100 & 1.135 & .259 \\
\hline & keunggulan produk baru & .363 & .051 & .624 & 7.098 & .000 \\
\hline
\end{tabular}

a. Dependent Variable: tingkat kesuksesan produk baru

Sumber: data primer diolah 2015

Persamaan regresi:

$Y_{1}=0.100 X_{1}+0.624 X_{2}$

Dimana:

$\mathrm{Y}_{1}=$ Tingkat kesuksesan produk baru .

$\mathrm{X}_{1}=$ Keguna baruan produk.

$\mathrm{X}_{2}=$ Keunggulan produk baru. 
Tabel 2. Analisis Regresi (uji t)

Koefisien regresi untuk $\mathrm{Y}_{2}$ (Kinerja pemasaran)

Coefficients $^{\mathrm{a}}$

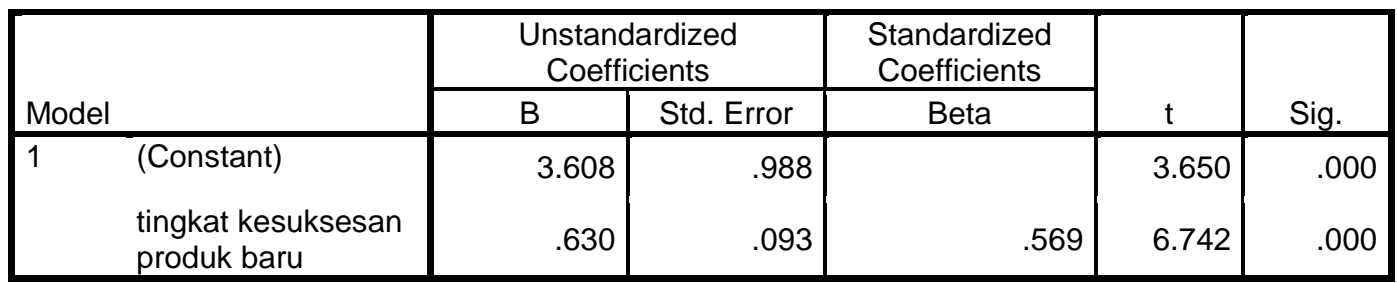

a. Dependent Variable: kinerja pemasaran

Sumber: data primer diolah 2015

Persamaan regresi:

$Y_{2}=0.569 Y_{1}$

Dimana:

$\mathrm{Y}_{2}=$ Kinerja pemasaran. $\quad \mathrm{Y}_{1}=$ Tingkat kesuksesan produk baru.

\section{Pengujian Hipotesis Pertama}

Menjawab perumusan masalah pertama yaitu pengujian variable kegunaan produk terhadap tingkat kesuksesan produk baru menghasilkan nilai $t_{\text {hitung }}$ sebesar $(1.135)<t_{\text {tabel }}(1.986)$ atausignifikansi $(0.259)>(0.05)$, maka daerah $\mathrm{H}_{0}$ diterima, yaitutidak ada pengaruh signifikan antara kegunaan produk terhadap tingkat kesuksesan produk baru.

\section{Pengujian Hipotesis Kedua}

Menjawab perumusan masalah kedua yaitu pengujian variable kegunaan produk terhadap tingkat kesuksesan produk baru menghasilkan nilai $t_{\text {hitung }}$ sebesar (7.098) $>t_{\text {tabel }}(1.986)$ atausignifikansi $(0.000)<(0.05)$, maka daerah $\mathrm{H}_{0}$ ditolak, yaituada pengaruh signifikan antara keunggulan produk baru terhadap tingkat kesuksesan produk baru.Hasil ini menunjukkan apabila semakin tinggi kepercayaan konsumen bahwa produk memiliki keunggulan produk baru, maka semakin tinggi juga tingkat kesuksesan produk baru.

\section{Pengujian Hipotesis Ketiga}

Menjawab perumusan masalah pertama yaitupengujian variable tingkat kesuksesan produk baru terhadap kinerja pemasaran menghasilkan nilai $t_{\text {hitung }}$ sebesar $(6.742)>t_{\text {tabel }}(1.986)$ atausignifikansi $(0.000)<(0.05)$, maka daerah $\mathrm{H}_{0}$ ditolak, yaituada pengaruh signifikan antara tingkat kesuksesan produk baru 
terhadap kinerja pemasaran.Hasil ini menunjukkan apabila semakin tinggi tingkat kesuksesan produk baru, maka semakin tinggi juga kinerja pemasaran.

\section{Hasil Pengujian Koefisien Determinasi atau Uji Adjusted $\mathbf{R}^{2}$}

Tabel 3. Hasil Uji Adjusted $\mathbf{R}^{2}$

\begin{tabular}{|l|l|l|l|}
\hline \multicolumn{1}{|c|}{ Model } & \multicolumn{1}{c|}{ R } & R Square & Adjusted R Square \\
\hline Tingkat kesuksesan produk baru & 0.680 & 0.463 & 0.451 \\
\hline Kinerja pemasaran & 0.569 & 0.324 & 0.317 \\
\hline
\end{tabular}

Sumber: data primer diolah 2015

Berdasarkan table diatas diketahui besarnya adjusted $R^{2}$ untukY $Y_{1}$ (tingkat kesuksesan produk baru) sebesar 0.451 , berarti $45 \%$ variasi tingkat kesuksesan produk baru bisa dijelaskan oleh variabel independen kegunaan produk dan keunggulan produk baru, sedangkan sisanya sebesar 55\% dijelaskan oleh factor lain yang tidak diteliti atau diluar model.

Berdasarkan table diatas diketahui besarnya adjusted $R^{2}$ untukY 2 (kinerja pemasaran) sebesar 0.317 , berarti $32 \%$ variasi kinerja pemasaran bisa dijelaskan oleh variasi dari variabel independen tingkat kesuksesan produk baru, sedangkan sisanya sebesar $68 \%$ dijelaskan oleh factor lain yang tidak diteliti atau diluar model.

\section{Hasil Sobel Test}

Tabel 4. Hasil Sobel Test Kegunaan Produk Terhadap Kinerja Pemasaran

Results

\begin{tabular}{|l|l|}
\hline Indirect Effect $(\mathrm{a} . \mathrm{b})$ & 0.241 \\
\hline Sobel's SE $=\sqrt{\left[(\mathrm{a} . \mathrm{SEb})^{2}+(\mathrm{a} . \mathrm{SEb})^{2}\right]}$ & 0.064 \\
\hline $\mathrm{Z}=$ Indirect Effect $\div$ Sobel's SE & 3.795 \\
\hline $\mathrm{P}$ & 0.000 \\
\hline Standardized Indirect Effect $=\left(\beta_{\mathrm{a}} \cdot \beta_{\mathrm{b}}\right)$ & 0.235 \\
\hline Portion of $(\mathrm{X} \rightarrow \mathrm{Y})$ due to $\mathrm{M}=(\mathrm{c}-\mathrm{c}$ ' $) / \mathrm{c}$ & $45.5 \%$ \\
\hline
\end{tabular}

Sumber: data primer diolah 2015

Nilai total indirect effect $(3.795)>$ standardized indirect effect $(0.235)$, menunjukkan bahwa pengaruh mediasi menguatkan. 
Tabel 5. Hasil Sobel Test Kegunaan produk baru Terhadap Kinerja Pemasaran

Results

\begin{tabular}{|l|l|}
\hline Indirect Effect $(\mathrm{a} \cdot \mathrm{b})$ & 0.247 \\
\hline Sobel's SE $=\sqrt{\left[(\mathrm{a} \cdot \mathrm{SEb})^{2}+(\mathrm{a} \cdot \mathrm{SEb})^{2}\right]}$ & 0.045 \\
\hline $\mathrm{Z}=$ Indirect Effect $\div$ Sobel's SE & 5.475 \\
\hline $\mathrm{P}$ & 0.000 \\
\hline Standardized Indirect Effect $=\left(\beta_{\mathrm{a}} \cdot \beta_{\mathrm{b}}\right)$ & 0.383 \\
\hline Portion of $(\mathrm{X} \rightarrow \mathrm{Y})$ due to $\mathrm{M}=\left(\mathrm{c}-\mathrm{c}^{\prime}\right) / \mathrm{c}$ & $39.9 \%$ \\
\hline
\end{tabular}

Sumber: data primer diolah 2015

Nilai total indirect effect $(5.475)>$ standardized indirect effect $(0.383)$, menunjukkan bahwa pengaruh mediasi menguatkan.

\section{Pembahasan}

Berdasarkan analisis data dan pengujian hipotesis yang diperoleh bahwa kegunaan produk mempunyai pengaruh positif dan tidak ada pengaruh signifikan terhadap tingkat kesuksesan produk baru secara persial.Perusahaan harus dapat menciptakan kegunaan yang lebih terhadap telepon seluler, yang dapat menarik persepsi konsumen seperti dapat membantu dalam berkomunikasi, membantu mendapatkan informasi dari internet, kegunaan dalam transaksi keuangan (mobile banking), dan kegunaan aplikasi dalam membantu pekerjaan.

Berdasarkan analisis data dan pengujian hipotesis yang diperoleh bahwa keunggulan produk baru mempunyai pengaruh positif dan signifikan terhadap tingkat kesuksesan produk baru secara persial. Semakin tinggi kepercayaan konsumen bahwa produk memiliki keunggulan dibandingkan produk yang lain, maka semakin tinggi pula tingkat kesuksesan produk. Perusahaan akan dapat menciptakan keunggulan produk telepon seluler sesuai dengan keinginan pasar, yang dapat menarik konsumen seperti desain dan warna yang unik, kualitas produk telepon seluler Polytron, produk selalu mengikuti trend/kekinian, memiliki teknologi canggih atau kehandalan, dan memiliki produk-prodik terbaru da inovatif. Hasil ini didukung penelitian yang dilakukan oleh Okky (2003), Nurul \& Fitri (2006) yang menyatakan keunggulan produk baru berpengaruh positif dan signifikan terhadap tingkat kesuksesan produk baru. 
Berdasarkan analisis data dan pengujian hipotesis yang diperoleh bahwa tingkat kesuksesan produk baru mempunyai pengaruh positif dan signifikan terhadap kinerja pemasaran secara persial.Semakin tinggi tingkat kesuksesan produk baru maka semakin tinggi pula kinerja pemasaran. Perusahaan akan dapat menciptakan keunggulan produk untuk mendorong tingkat kesuksesan produk baru dengan menjadikan telepon seluler Polytron menarik untuk dibeli, menjadikan persepsi konsumen untuk mengutamakan atau prioritas telepon seluler bahwa lebih unggul daripada yang lain, dan produk telepon seluler patut untuk dibeli kembali. Hasil ini didukung penelitian yang dilakukan oleh Okky (2003) yang menyatakan tingkat kesuksesan produk baru berpengaruh positif dan signifikan terhadap kinerja pemasaran.

Hasil Sobel Test pengaruh kegunaan produk terhadap kinerja pemasaran dengan mediasi tingkat kesuksesan produk baru adalah menguatkan, sedangkan pengaruh keunggulan produk baru terhadap kinerja pemasaran dengan mediasi tingkat kesuksesan produk baru adalah menguatkan. Ini berarti untuk meningkatkan kinerja pemasaran yang baik dengan pengaruh tidak langsung melalui kegunaan produk dan keunggulan produk baru dengan tingkat kesuksesan produk baru sebagai variabel intervening.

\section{PENUTUP}

\section{Kesimpulan}

Berdasarkan pada hasil analisis dan pembahasan, maka dapat diambil beberapa kesimpulan sebagai berikut :

1. Hipotesis pertama yang menyatakan bahwa variabel kegunaan produk mempunyai pengaruh yang positif dan tidak ada pengaruh signifikan terhadap tingkat kesuksesan produk baru pada produk telepon seluler Polytron.

2. Hipotesis kedua yang menyatakan bahwa variable keunggulan produk baru mempunyai pengaruh positif dan signifikan terhadap tingkat kesuksesan produk baru pada produk telepon seluler Polytron. Hasil ini menunjukkan apabila semakin tinggi kepercayaan konsumen bahwa produk memiliki 
keunggulan produk baru, maka semakin tinggi juga tingkat kesuksesan produk baru.

3. Hipotesis ketiga yang menyatakan bahwa variable tingkat kesuksesan produk baru mempunyai pengaruh positif dan signifikan terhadap kinerja pemasaran pada produk telepon seluler Polytron. Hasil ini menunjukkan apabila semakin tinggi tingkat kesuksesan produk baru, maka semakin tinggi juga kinerja pemasaran.

4. Pengaruh kegunaan produk terhadap kinerja pemasaran dengan mediasi tingkat kesuksesan produk baru adalah menguatkan, sedangkan pengaruh keunggulan produk baru terhadap kinerja pemasaran dengan mediasi tingkat kesuksesan produk baru adalah menguatkan.

\section{Saran-Saran}

Saran yang dapat dikemukakan pada penelitian ini antara lain:

1. Berdasarkan hasil penelitian variabel kegunaan produk dimana indikator yang memiliki skor paling rendah yaitu pentingnya produk pada pekerjaan perlu ditingkatkan dan kegunaan produk yang mempunyai pengaruh positif terhadap tingkat kesuksesan produk baru perlu ditingkatkan juga.

2. Berdasarkan hasil penelitian variabel keunggulan produk baru dimana indikator yang memiliki skor paling rendah yaitu produk benar-benar baru dan inovatif perlu ditingkatkan dan keunggulan produk baru yang mempunyai pengaruh positif terhadap tingkat kesuksesan produk baru perlu ditingkatkan juga.

3. Berdasarkan hasil penelitian variabel tingkat kesuksesan produk baru dimana indikator yang memiliki skor paling rendah yaitu keputusan konsumen untuk membeli kembali varian produk pada waktu lain perlu ditingkatkan dan mempunyai pengaruh positif terhadap kinerja pemasaran perlu ditingkatkan juga.

4. Membuat suatu ukuran dan standar untuk meningkatkan kinerja pemasaran dalam suatu perusahaan, perusahaan harus memperhatikan setrategi untuk membantu agar mampu mencapai standar kinerja pemasaran yang ditetapkan. 


\section{DAFTAR PUSTAKA}

Baron, R. M., \& Kenny, D. A. (1986). The moderator-mediator variable distinction in social psychological research: Conceptual, strategic and statistical considerations. Journal of Personality and Social Psychology, Vol. 51, 1173-1182.

Cornelius, 17 Juni 2015. Kewajiban TKDN: Apple Inc. Akhirnya Nyerah. (Online), (http://www.hprpdailynews.com/2015/06/17/kewajiban-tkdnapple-inc-akhirnya-nyerah/).Bisnis Indonesia.

Ferdinad, A. 2013, Metode Penelitian Manajemen, Edisi IV, Semarang: Universitas Diponegoro.

Ghozali, Imam. 2012. Aplikasi Analisis Multivariabel Dengan Program IBM SPSS 20. Semarang: Universitas Diponegoro.

Komaryatin, Nurul dan Fitri, E.F. 2006.Analisi Pengaruh Keunggulan Produk Kegunaan produk dan Promosi Terhadap Tingkat Kesuksesan Produk Telkomel Flexi Di Jepara.Vol. 3, No. 2, hlm 155-172.

Kotler, Philip \& Keller, K. L. 2009.Manajemen Pemasaran, Jilid 1, Alih bahasa Bob Sabran. Jakarta: Erlangga.

Kotler, Philip \& Keller, K. L. 2009.Manajemen Pemasaran, Jilid 2, Alih bahasa Bob Sabran. Jakarta: Erlangga.

Kuncoro, Mudrajad. 2003. Metode Riset untuk Bisnis \& Ekonomi. Jakarta: Erlangga.

Li, Tiger and Roger J. Calantone. 1998. The Impact of Market Knowledge Competence on New Product Advantage: Conceptualization and Empirical Examination.Journal of marketing, Vol. 62, hlm 13-29.

Muharsyah, Rian, dkk. Pengaruh Tingkat Pertumbuhan Penjualan dan Perputaran Piutang Terhadap Likuiditas Perusahaan pada Perusahaan Otomotif dan Komponennya yang Terdaftar di Bursa Efek Indonesia.STIE MDP.

Navarone, Okky. 2013. Analisis Pengaruh Tingkat Kesuksesan Produk Baru Dalam Peningkatan Kinerja Pemasaran. Jurnal Sains Pemasaran Indonesia, Vol. II, No. 1, hlm 111-122.

Priyatno, Duwi. 2010. Teknik Mudah Dan Cepat Melakukan Analisis Data Penelitian dengan SPSS. Yogyakarta: Gava Media.

Putranto, Samtim, E. 2003. Studi Mengenai Orientasi Strategi dan Kinerja Pemasaran.Jurnal Sains Pemasaran Indonesia, Vol. II, No. 1, hlm 93-110.

Siswanto, S. 2009. Manajemen Pemasaran. Jakarta: PT. Damar Mulia Pustaka.

Sugiyono. 2013. Metode Penelitian Pendidikan Pendekatan Kualitatif, Kuantitatif, dan $R \& D$. Bandung: Alfabeta.

Sugiyono. 2014. Metode Penelitian Kuantitatif, Kualitatif Dan R\&D. Bandung: Alfabeta.

Umar, Husein. 2003. Metode Riset Akutansi Terapan. Jakarta: Ghalia Indonesia.

Widodo. 2008. Meningkatkan Kinerja Pemasaran Dengan Kriativitas Strategi. Universitas Sultan Agung: Vol.1, No. 2, hlm 151-175. 